\title{
Myofibroblastic tumor of the esophagus - a case report of long-term follow-up and literature review
}

\author{
Myofibroblastický nádor jícnu - kazuistika, dlouhodobý follow-up \\ a přehled literatury
}

\author{
Vaculová J. ${ }^{1}$, Dolina J. ${ }^{1}$, Jabandžiev P. ${ }^{2,3}$, Štěrba M. ${ }^{2}$, Tůma J. ${ }^{4}$, Doušek R. ${ }^{4}$, Plánka L. ${ }^{4}$ Šenkyř́ík J. ${ }^{5}$, Štěrba J. ${ }^{6}$, \\ Bajčiová V. ${ }^{6}$, Eid M. ${ }^{7}$, Pavlovský Z. ${ }^{8}$, Kala Z. ${ }^{9}$, Kunovský L. ${ }^{1,9}$

\begin{abstract}
1 Department of Gastroenterology and Internal Medicine, University Hospital Brno, Faculty of Medicine, Masaryk University, Brno, Czech Republic 2 Department of Pediatrics, University Hospital Brno, Faculty of Medicine, Masaryk University, Brno, Czech Republic

${ }^{3}$ Central European Institute of Technology, Masaryk University, Brno, Czech Republic

${ }^{4}$ Department of Pediatric Surgery, Orthopedics and Traumatology, University Hospital Brno, Faculty of Medicine, Masaryk University, Brno, Czech Republic ${ }^{5}$ Department of Pediatric Radiology, University Hospital Brno, Faculty of Medicine, Masaryk University, Brno, Czech Republic

${ }^{6}$ Department of Pediatric Oncology, University Hospital Brno, Faculty of Medicine, Masaryk University, Brno, Czech Republic

${ }^{7}$ Department of Hematology, Oncology and Internal Medicine, University Hospital Brno, Faculty of Medicine, Masaryk University, Brno, Czech Republic ${ }^{8}$ Department of Pathology, University Hospital Brno, Faculty of Medicine, Masaryk University, Brno, Czech Republic

${ }^{9}$ Department of Surgery, University Hospital Brno, Faculty of Medicine, Masaryk University, Brno, Czech Republic
\end{abstract}

\begin{abstract}
Summary
Background: Inflammatory myofibroblastic tumor (IMT) is a rare mesenchymal neoplasm with intermediate malignant potential. Although most often seen in the lungs, it can occur at multiple anatomical locations, including the gastrointestinal tract. An esophageal lesion is extremely rare, however. IMTs present most commonly in children and young adults. The main therapeutic approach is surgical resection. Case report: We report on the follow-up of a case in a 13-year-old boy with IMT in the esophagus. He underwent surgical resection in 2013 and is free of disease to date. Conclusion: Surgical resection is the most preferred therapy. If the resection is complete, the risk of recurrence is low. Nevertheless, every patient should be carefully followed up after the resection.
\end{abstract}

\section{Key words}

inflammatory pseudotumor - esophageal carcinoma - myofibroblastic tumor - plasma cell granuloma - endoscopy - surgery

\section{Souhrn}

Východiska: Zánětlivý myofibroblastický nádor jícnu je vzácná mezenchymální neoplazie středně maligního potenciálu. Přestože se nejčastěji vyskytuje v plicích, může se objevit v mnoha jiných anatomických lokalizacích vč. gastrointestinálního traktu, avšak postižení jícnu je velmi vzácné. Myofibroblastický nádor jícnu se nejčastěji manifestuje u dětí a mladých dospělých. Základním terapeutickým postupem je chirurgická resekce. Kazuistika: V této kazuistice prezentujeme prípad 13letého chlapce s myofibroblastickým nádorem jícnu, který podstoupil chirurgickou resekci v roce 2013 a od té doby je v trvalé remisi. Závěr: Chirurgická léčba je nejvíce upřednostňovanou metodou léčby. $V$ prípadě kompletní resekce je riziko recidivy nízké. Nicméně každého pacienta po resekci je třeba pečlivě dispenzarizovat.

\section{Klíčová slova}

zánětlivý pseudotumor - karcinom jícnu - myofibroblastický tumor - granulom z plazmatických buněk - endoskopie - chirurgie
Supported by the Ministry of Health of the Czech Republic - grant No. NU20-03-00126, and Ministry of Health of the Czech Republic conceptual development of research organization $(\mathrm{FNBr}, 65269705$, SUp 3/21).

Podpořeno MZ ČR - grant č. NU20-03-00126 a MZ ČR konceptuální rozvoj výzkumné organizace (FNBr, 65269705, SUp 3/21).

The authors declare they have no potential conflicts of interest concerning drugs, products, or services used in the study.

Autoři deklarují, že $v$ souvislosti s předmětem studie nemají žádné komerční zájmy.

The Editorial Board declares that the manuscript met the ICMJE recommendation for biomedical papers.

Redakční rada potvrzuje, že rukopis práce splnil ICMJE kritéria pro publikace zasílané do biomedicínských časopisů.

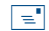

Lumír Kunovský, MD, PhD Department of Gastroenterology and Internal Medicine, University Hospital Brno Jihlavská 20, 62500 Brno

Czech Republic e-mail: kunovsky.lumir@fnbrno.cz

Submitted/Obdrženo: 3. 3. 2021 Accepted/Prijato: 25. 4. 2021 


\section{Introduction}

Inflammatory myofibroblastic tumor (IMT) is a rare neoplasm that can occur in various anatomical locations but appears most commonly in the lungs and mesentery or omentum [1,2]. Although these lesions have been found in nearly every anatomical location, there are only a few documented cases of esophageal localization [3]. Microscopically, IMT consists of inflammatory cells and spindleshaped cells that are either fibroblasts or myofibroblasts [4]. IMT is equally distributed across genders [1,2] and can occur at any age; however, it presents most commonly in children and young adults [5]. Although IMTs are generally benign, they are classified as interme-

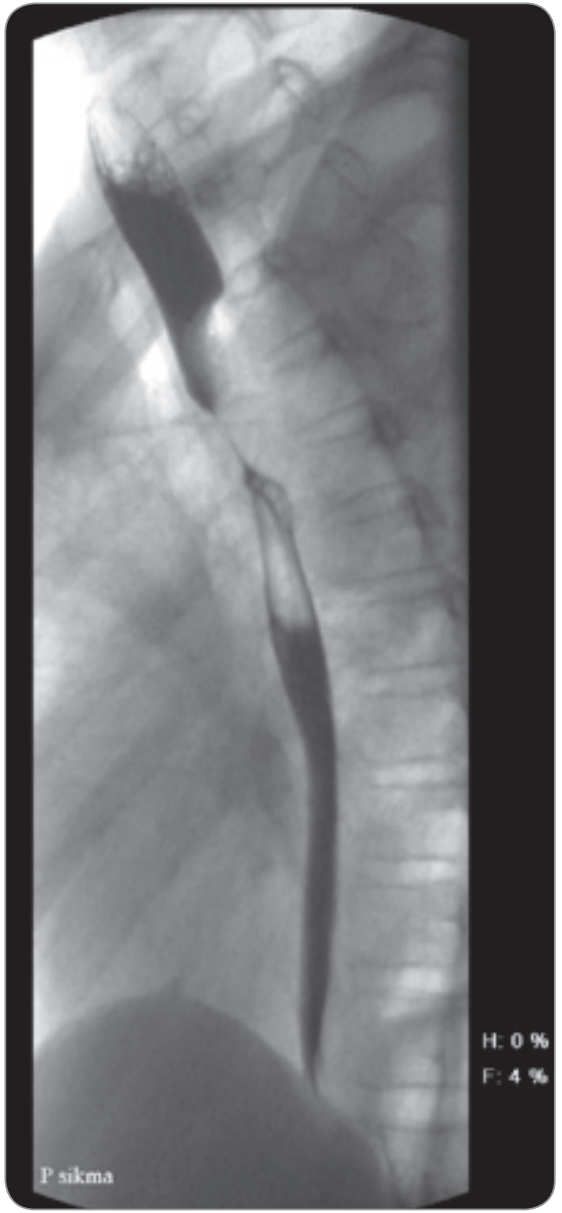

Fig. 1A. Oblique projection skiagram, passage through the esophagus, orally administrated barium contrast agent.

Image shows a sharply contoured tight stenosis of the esophagus at the interface of the oral and middle thirds of the esophagus, dorsal impression, prolonged passage. diate tumors because of the rare possibility of recurrence $[6,7]$.

Distinguishing features of IMT (15$30 \%$ of cases) include the presence of inflammatory syndrome consisting of fever, weight loss, nausea, anemia, thrombocytosis, polyclonal hyperglobulinemia, and elevated erythrocyte sedimentation rate that has been attributed to cytokine stimulation [8]. Various pathogenetic backgrounds have been proposed as initiating factors, such as reactive infections and autoimmune or neoplastic processes, but the etiology of most cases remains unknown [9]. The most commonly reported curative therapy of IMT is surgical resection $[4,10]$.

A case report of this patient was published in 2015 [11], and we now present data from a long-term follow-up.

\section{Case report}

We report the case of IMT in a 13-year-old boy, who presented with a 2-month history of dysphagia. There were no other symptoms or weight loss. There was no evidence of any consumption of chemicals or foreign bodies. In the patient's personal anamnesis, there was only a case of pneumonia, which he had suffered from when he was 18 months old. No comorbidities were found. His father had suffered from a melanoma of the right upper limb, which remains in remission after surgical resection. The results of a physical examination of the patient were unremarkable; laboratory data showed no abnormalities except mild anemia and marginal leukopenia. A barium meal examination of the upper digestive tract revealed a filiform stenosis above level Th4/5, $14 \mathrm{~mm}$ in length, with prestenotic dilatation (Fig. 1A). A CT scan detected a lesion of size $25 \times 20 \times 15 \mathrm{~mm}$ in the posterior mediastinum, coming from the wall of the esophagus (Fig. 1B). In the endoscopic ultrasound, an intramural lesion of the esophageal wall was identified. It involved approximately two-thirds the circumference of the esophageal lumen. There were no signs of infiltration in the surroundings of the esophagus. The patient also underwent gastroscopy, which revealed esophageal stenosis $20 \mathrm{~cm}$ from the incisors that was impassable for the endoscope. A biopsy did not show any malignant changes. Therefore, a thoracotomy was carried out, taking a second biopsy from the esophagus. The histological analysis of this perioperative biopsy confirmed IMT. In 2013, the patient was prepared for a radical surgical resection of the thoracic part of the esophagus, which was replaced by a part of the stomach. An intrathoracic esophagogastric anastomosis was performed. A perioperative view of the tumor can be seen in Fig. 2. During the operation a nutritional jejunostomy was inserted. Postoperatively, the patient developed a catheter sepsis and

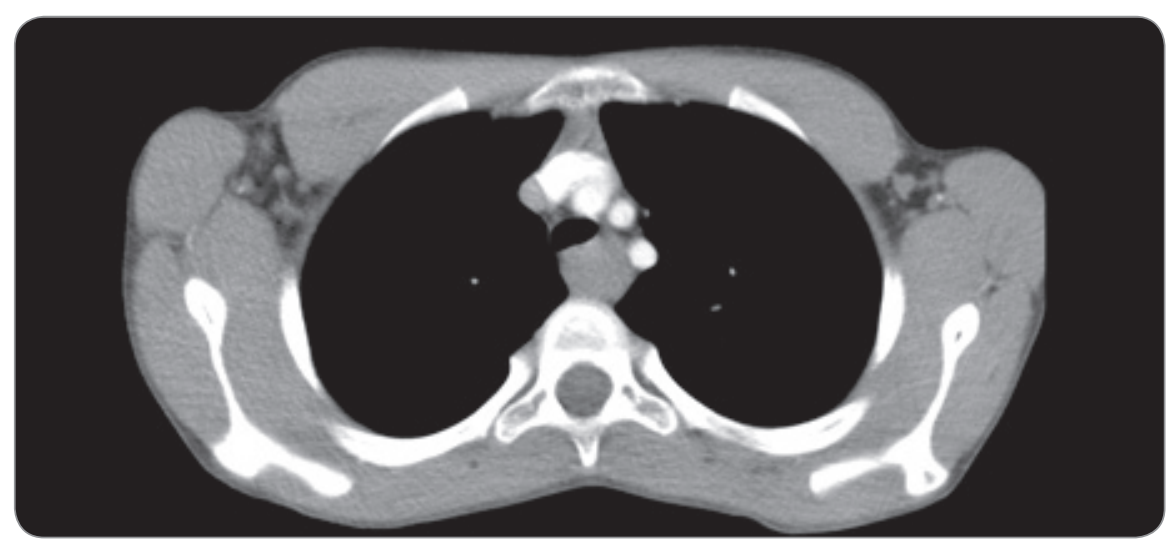

Fig. 1A. Axial CT scan at the level of the left brachiocephalic vein after intravenous application of iodine contrast agent.

Hypodense expansion of the posterior mediastinum, slightly compressing the trachea, displacing the esophagus ventrolaterally to the left, visible after the administration of a contrast agent isodensic with the chest muscles. It is not possible to differentiate the boundary of the expansion from the esophageal wall (intramural lesions). 
was treated with antibiotics. Afterwards, he tolerated a regular diet and the nutritional jejunostomy was removed. A final histology confirmed the diagnosis of IMT (Fig. 3A-C). In the postoperative course, the stenosis formed in the anastomosis and the patient repeatedly underwent several series of esophageal dilations with good results. As part of an oncology consultation, the patient has been followed up annually with upper GIT endoscopy. After a follow-up period of 8 years, he is symptom-free and there has been no endoscopic evidence of recurrence (Fig. 4 includes endoscopic images from 2020).

\section{Discussion}

IMT is a very rare neoplasm and mostly occurs in the soft tissue of children and young adults, with the lungs as the most commonly affected site, though it has been recognized in many anatomical localizations, such as in the peritoneum, colon, liver, bladder, breast, and nasal cavity [12]. Histologically, IMT includes myofibroblastic and fibroblastic spindle cells with variable inflammatory infiltration by lymphocytes, plasma cells, eosinophils, and histiocytes $[13,14]$.

Differential diagnoses of IMTs include other submucosal lesions, such as leiomyoma and gastrointestinal stromal tumors and other benign non-neoplastic tumorous lesions, including inflammatory fibroid polyps, fibrovascular polyps, and inflammatory polyps, as these lesions are composed of fibroblastic cells and inflammatory cells, the same as IMT. The differentiation of these lesions from IMT is therefore rather difficult [15-17].

IMT exhibits variable biological behavior ranging from frequently benign lesions to more aggressive variants. It remains a topic of discussion whether IMT should be considered a tumor or inflammation, and also whether it is normally benign or malignant. Local recurrence is possible, although it rarely metastasizes [12].

Approximately $50 \%$ of IMTs are positive for anaplastic lymphoma kinase (ALK) expression as confirmed by immunohistochemistry. ALK-negative IMTs may be more aggressive, with higher fre-

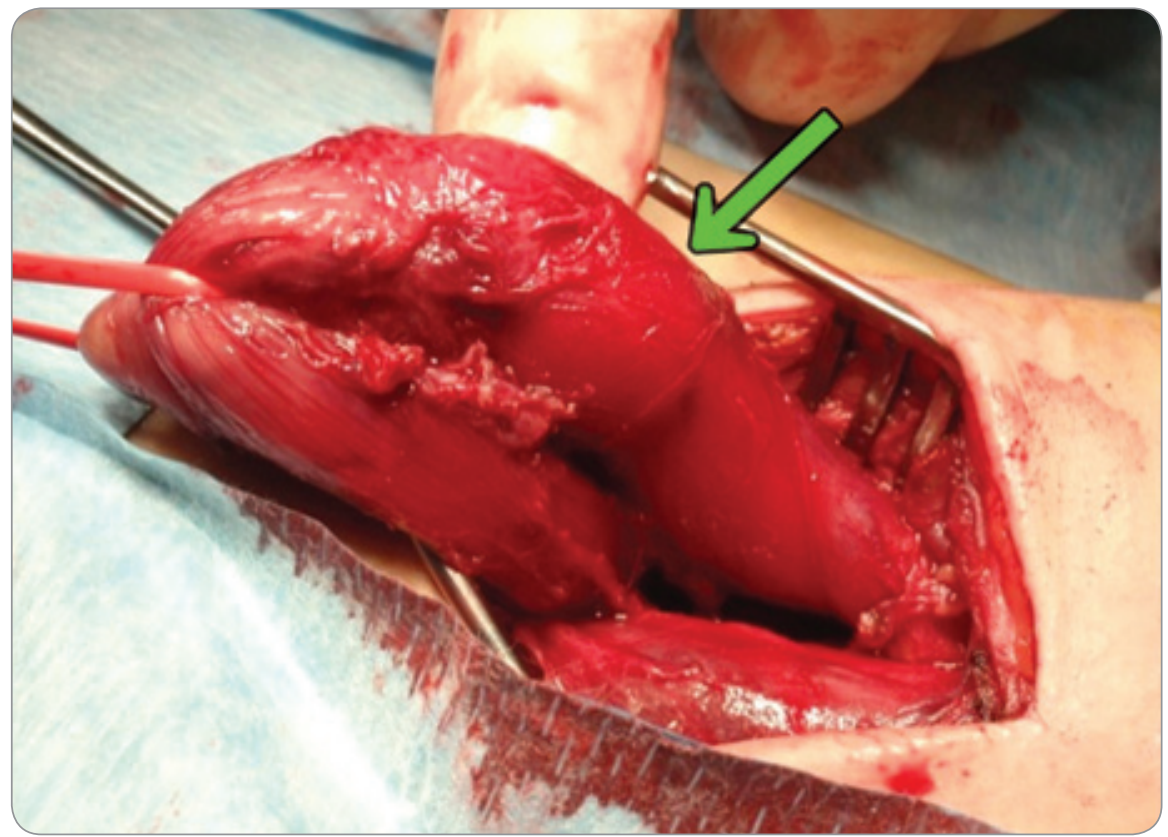

Fig. 2. Peroperative view. The esophageal tumor is indicated by an arrow.

quency of metastasis compared to ALKpositive IMTs [18]. For patients with ALKpositive IMT with unresectable tumors or with advanced stage IMT, ALK inhibition can be an effective therapy [19].

The exact etiology of IMT is still unknown; however, commonly reported etiologies include the Epstein-Barr virus, human herpes virus 8 infection, trauma, reflux, and overexpression of interleukin $6[2,13]$.

IMT is very rare in the esophagus and to date there are few such cases reported in the English-language literature. Although it is seen mostly in children and young adults, the disease can occur at any age. The most frequent symptoms of esophageal IMTs are dysphagia, substernal pain, and inflammatory features related to cytokine release, such as fever, weight loss, and elevated acute phase reactants [20].

The basic treatment strategy is radical surgery, which also helps to confirm the diagnosis by histopathological examination and immunohistochemistry. In the case of esophageal location, this mostly means esophagectomy, and gastric transposition is the preferred type of esophageal replacement. After resection, if radicality was not achieved, a higher rate of recurrence is expected. Enucleation or endoscopic excision are also reported [11,21]. Goldin et al [22] and Santa Cruz et al [23] have described surgical resection as their first choice of treatment. Although surgery is the most common therapy for IMT, there remains a risk of complications. Seco et al have reported the case of a 19-year-old woman with esophageal IMT who underwent a partial esophagectomy and upon whom a reoperation was later performed due to dehiscence of the anastomosis. Eleven days later, she died of sepsis [21].

In case of inoperable tumor, radiotherapy or chemotherapy should be considered. Patients with ALK-positive unresectable IMTs have an effective treatment option in targeted molecular therapy $[11,24]$. Crizotinib is a smallmolecule tyrosine-kinase inhibitor of ALK, ROS1 and another proto-oncogene receptor tyrosine kinase, MET. Lovly et al reported a patient with ALK-negative IMT in the mediastinum who was treated with the ALK inhibitor crizotinib. This was a 6-year-old boy with a 1-year history of coughing and fatigue having an IMT in the mediastinum that was unresectable due to its intimate association with the pulmonary vein, aorta, and esophagus. After the treatment with crizotinib, there was a decrease in the size of his tumor mass. Since molecular tumor 

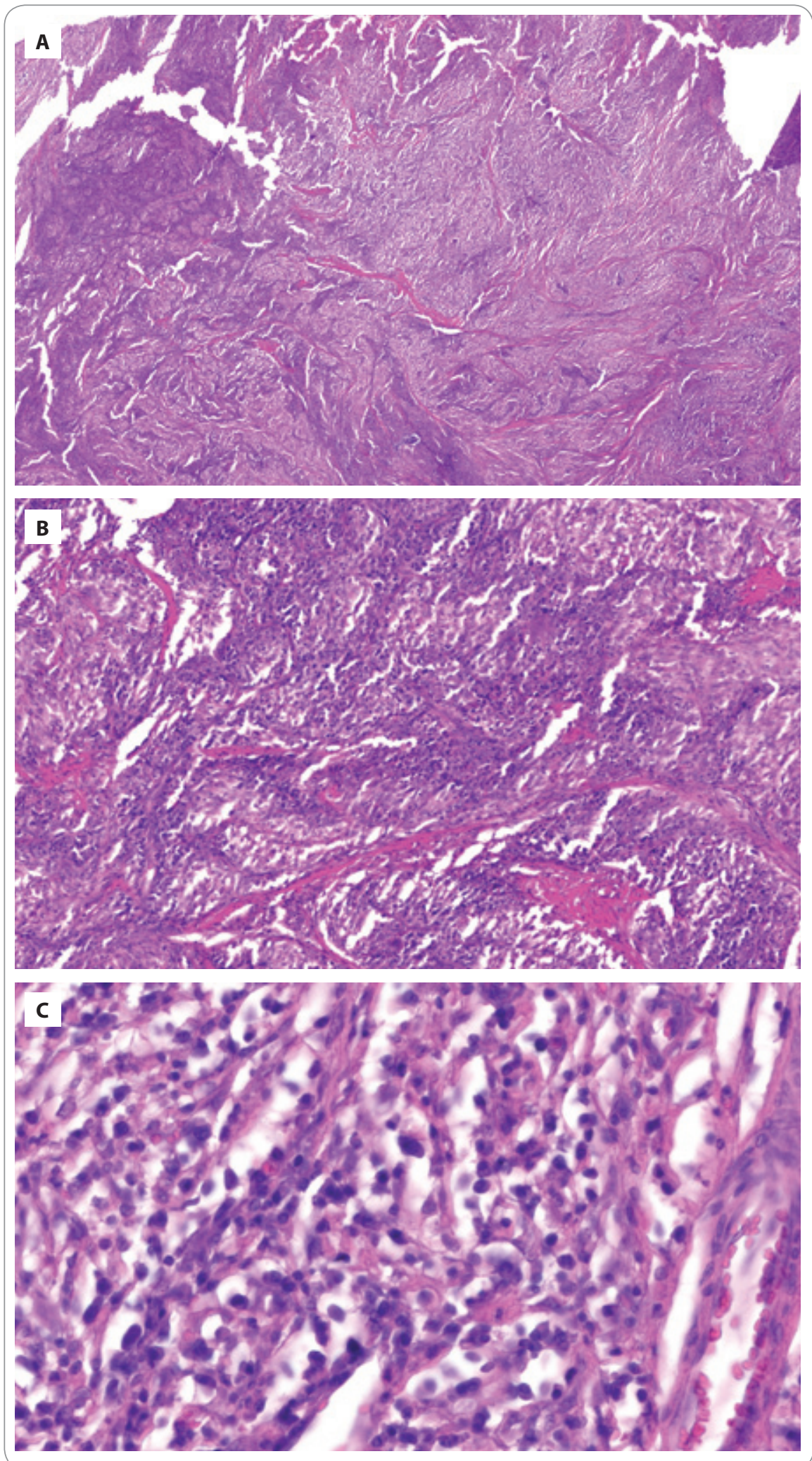

Fig. 3. Histopathology.

Hematoxylin and eosin stain of the esophageal tumor showing features consistent with inflammatory myofibroblastic tumor. Spindle cells with a fascicular pattern and nuclear atypia are seen in the background of mixed inflammation with variable myxoid stroma. A) Hematoxylin and eosin, 10x; B) hematoxylin and eosin, 50x; C) hematoxylin and eosin, $200 x$. profiling revealed a ROS1 fusion in this case, there was a dramatic response to the treatment with the ROS1 inhibitor. Therefore, crizotinib is also used for the treatment of ALK-negative IMT with ROS1 fusion [18,25].

In 2021, Zhang et al reported a retrospective analysis of 23 child patients with pulmonary IMT, all of whom had undergone surgical treatment with a 5 -year overall survival rate of $100 \%$. Two patients developed local recurrence and reoperations were performed (both of them exhibited ALK-negative tumors). All patients survived until the end of the study. According to the authors of this study, consideration could be given to the concept of reducing the risk of surgical morbidity in large, difficult, multifocal ALK-positive tumors by the treatment with an ALK inhibitor prior to definitive surgical resection [26].

In 2020, Song et al presented another retrospective study of 17 patients (aged 16-56 years). The most commonly identified locations were the bronchi and the lungs, but there were also occurrences in the gastrointestinal and urogenital tracts. Sixteen of these patients underwent tumor resection, and one patient died due to tumor progression. During the follow-up period, two patients relapsed and both of them underwent surgery again. At the end of the study, they were still alive. One patient was lost from the follow-up, 13 of them were ultimately reported as cured [27].

In 2020, Casanova et al reported a prospective study of 60 patients with IMT (all of them were $<25$ years old). Patients were prospectively registered for The European Pediatric Soft Tissue Sarcoma Study Group database from September 2005 to December 2016 in 9 different countries. They were staged according to the Intergroup Rhabdomyosarcoma Study grouping system, depending on the amount and extent of residual tumor after initial surgery (group I - complete $\mathrm{R} 0$ resection, group II - R1 resection with microscopic residual disease or regional lymph nodal spread, group III - R2 resection with macroscopic residual disease or biopsy alone, group IV - metastases at onset). In group I, 31 patients underwent complete R0 resection (4 of them devel- 

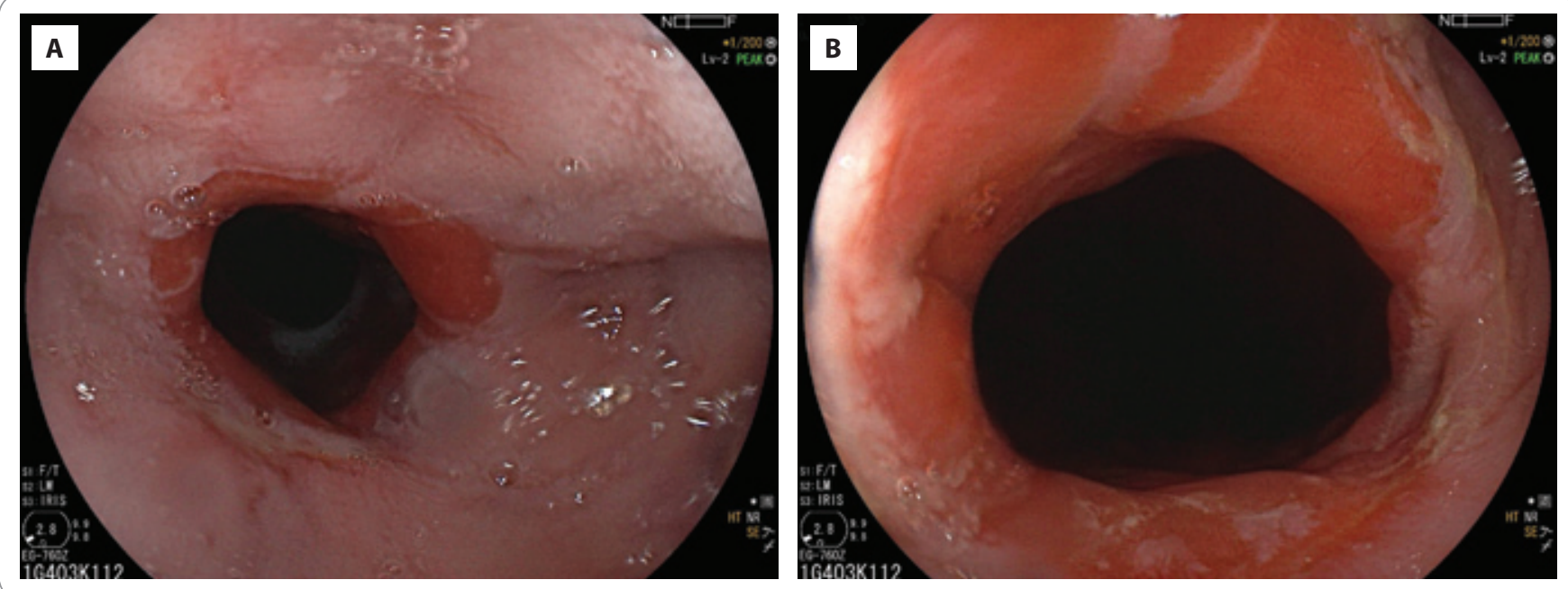

Fig. 4. Endoscopy.

Endoscopic view of esophagogastric anastomoses. No sign of disease recurrence.

oped a local relapse). In group II, 9 patients underwent resection ( 2 of them had nodal involvement), two patients with tumors relapsed. In Group III, 19 patients had macroscopic residual disease after R2 surgery. Out of them, 19 received various systemic treatment and one patient did not receive any therapy. One of the treated patients with ALK-negative lung IMT died of this disease 15 months after its diagnosis. In group IV, there was only one patient who was given chemotherapy with remission of the lesions. At the end of the study, all patients were alive, except the one patient from group III, who died. The study demonstrated a good overall prognosis for IMT, even for initially unresecable disease [28].

IMT rarely metastasizes, and it has a very low risk of recurrence. Lu et al reported the exceptional case of a 14-yearold boy with high-volume pelvic abdominal IMT and early tumor recurrence. It was the first reported case of IMT in the pelvic extraperitoneal perivesical space and the largest reported IMT $(30 \mathrm{~cm})$ among pediatric patients until that date. Although the tumor was completely resected, there was a recurrence just 20 days after the surgery. The patient refused further treatment and died 6 months later [29].

\section{Conclusion}

The occurrence of IMT in the esophagus is extremely rare, and only a few cases have been reported in the literature. Surgical resection is the most preferred type of therapy. If a tumor is completely resected, the risk of recurrence is very low. Nevertheless, every patient should be carefully followed up after the resection. In case of inoperable advanced disease, targeted molecular therapy could be effective. However, chemotherapy is still a valid option for the advanced stage.

\section{References}

1. Kovach SJ, Fischer AC, Katzman PJ et al. Inflammatory myofibroblastic tumors. J Surg Oncol 2006; 94(5): 385391. doi: 10.1002/jso.20516.

2. Attili SV, Chandra CR, Hemant DK et al. Retroperitoneal inflammatory myofibroblastic tumor. World J Surg Oncol 2005; 3: 66. doi:10.1186/1477-7819-3-66

3. Chen Y, Tang Y, Li H et al. Inflammatory myofibroblastic tumor of the esophagus. Ann Thorac Surg 2010; 89(2) 607-610. doi: 10.1016/j.athoracsur.2009.07.091.

4. Kurihara K, Mizuseki K, Ichikawa M et al. Esophageal inflammatory pseudotumor mimicking malignancy. Intern Med 2001; 40(1): 18-22. doi:10.2169/internalmedicine.40.18.

5. Privette A, Fisk P, Leavitt B et al. Inflammatory miofibroblastic tumor presenting with esopageal obstruction and an inflammatory syndrome. The annals of thoracic surgery 2008; 86(4): 1364-1367. doi: 10.1016/j.athoracsur.2008.03.056.

6. Jayarajah U, Bulathsingala RP, Sumana Handagala DM et al. Inflammatory miofibroblastic tumor of the oesophagus presenting with hematemesis and maelena: a case report and review of literatue. Clin Case Rep 2017: 6(1): 82-85. doi: 10.1002/ccr3.1296

7. Savvidou OD, Sakellariou VI, Papakonstantinou O et al. Inflammatory myofibroblastic tumor of the thigh: presentation of a rare case and review of the literature. Case Rep Orthop 2015; 2015: 814241. doi:10.1155/2015/814241.

8. Coffin CM, Hornick JL, Fletcher CD. Inflammatory myofibroblastic tumor: comparison of clinicopathologic, histologic, and immunohistochemical features including ALK expression in atypical and aggressive cases.
Am J Surg Pathol 2007; 31(4): 509-520. doi: 10.1097/01. pas.0000213393.57322.c7.

9. Palaskar S, Koshti S, Maralingannavar M et al. Inflammatory myofibroblastic tumor. Contemt Clin Dent 2011: 2(4): 274-277. doi: 10.4103/0976-237X.91787.

10. Marchi S, Costa F, Mumolo MG et al. Post-traumatic inflammatory pseudotumor of the esophagus. Gastrointest Endosc 2001; 54(3): 397-399. doi:10.1067/ mge.2001.116324

11. Dousek R, Tuma J, Planka L et al. Inflammatory myofibroblastic tumor of the esophagus in childhood: a case report and a review of the literature. J Pediatr Hematol Oncol 2015; 37(2): e121-124. doi: 10.1097/MPH. 0000000000000275.

12. Bjelovic M, Micev M, Spica B et al. Primary inflammatory myofibroblastic tumor of the stomach in an adult woman: a case report and review of the literature. World J Surg Oncol 2013; 11: 35. doi: 10.1186/1477-781911-35.

13. Inamdar AA, Pulinthanathu R. Malignant transformation of inflammatory myofibroblastic tumor of urinary bladder: A rare case scenario. Bladder (San Franc) 2019; 6(2): e39. doi: 10.14440/bladder.2019.805.

14. Pettinato G, Manivel JC, De Rosa N et al. Inflammatory myofibroblastic tumor (plasma cell granuloma). Clinicopathologic study of 20 cases with immunohistochemical and ultrastructural observations. Am J Clin Pathol 1990; 94(5): 538-546. doi: 10.1093/ajcp/94.5.538

15. Lewin K, Appelman H. Tumor of the esophagus and stomach, third series. Washington DC: Armed Forces Institute of Pathology 1996: 145-161

16. Kim Yl, Kim WH. Inflammatory fibroid polyp of gastrointestinal tract. Am J Clin Pathol 1988; 89(6): 721-727. doi: 10.1093/ajcp/89.6.721.

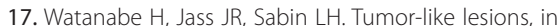
Histological Typing of Oesophageal and Gastric Tumours. 2nd ed. Berlin: Springer-Verlag 1990: 16-17.

18. Lovly CM, Gupta A, Lipson D et al. Inflammatory myofibroblastic tumors harbor multiple potentially actionable kinase fusions. Cancer Discov 2014; 4(8): 889-895. doi: 10.1158/2159-8290.CD-14-0377.

19. Mossé YP, Voss SD, Lim MS et al. Targeting ALK with crizotinib in pediatric anaplastic large cell lymphoma and inflammatory myofibroblastic tumor: a children's oncology group study. J Clin Oncol 2017; 35: 3215-3221.

20. Khakural P, Sapkota R, Shrestha UK et al. Successful surgical management of a rare esophageal inflammatory 
myofibroblastic tumour: a case report. J Cardiothorac Surg 2015; 10: 112. doi: 10.1186/s13019-015-0327-5.

21. Seco JL, Claver M, Bengoechea M et al. Plasma cel granuloma of the distal oesophagus. Br J Surg 1990; 77(9): 996-997. doi: 10.1002/bjs.1800770912.

22. Goldin SB, Osborne D, Paidas Cetal. Inflammatory myofibroblastic tumor of the midesophagus. Fetal Pediatr Patho 2007: 26(5-6): 243-254. doi: 10.1080/15513810801893421. 23. SantaCruz KS, McKinley ET, Powell RD Jr et al. Inflammatory myofibroblastic tumor of the gastroesophagea junction in childhood. Pediatr Pathol Mol Med 2002; 21(1): 49-56. doi: 10.1080/pdp.21.1.49.56.
24. Li J, Liu F, Wang Z et al. Inflammatory pseudotumo of the esophagus-Gl image. J Gastrointest Surg 2010; 14(1): 195-198. doi: 10.1007/s11605-009-0893-8. 25. Shaw AT, Ou SH, Bang YJ et al. Crizotinib in ROS1-rearranged non-small-cell lung cancer. N Engl J Med 2014 371(21): 1963-1971. doi: 10.1056/NEJMoa1406766. 26. Zhang N, Zeng Q, Chen C et al. Clinical characteristics and prognosis of pulmonary inflammatory myofibroblastic tumor: an over 10-year retrospective analysis. Pediat Investig 2020; 4(3): 192-197. doi: 10.1002/ped4.12218.

27. Song W, Zhu Y. Clinical characteristics and outcomes of 17 cases of inflammatory myofibroblastic tumor at a University Hospital in China. Oncol Lett 2021; 21(1): 51. doi: 10.3892/ol.2020.12312

28. Casanova M, Brennan B, Alaggio R et al. Inflammatory myofibroblastic tumor: The experience of the European pediatric Soft Tissue Sarcoma Study Group (EpSSG). Eur J Cancer 2020; 127: 123-129. doi: 10.1016/j. ejca.2019.12.021.

29. Lu CH, Huang HY, Chen HK et al. Huge pelvic-abdominal malignant inflammatory myofibroblastic tumor with rapid recurrence in a 14-year-old boy. World I Gastroenterol 2010; 16(21): 2698-2701. doi: 10.3748/wjg.v16. i21.2698. 